\title{
PROFITABILITY AND CONSTRAINTS OF PINEAPPLE PRODUCTION IN OSUN STATE, NIGERIA
}

\author{
Olayinka Isiaka BARUWA \\ Department of Agricultural Economics \\ Obafemi Awolowo University, Ile-Ife, Nigeria \\ Received: February 8, 2013; Accepted: July 9, 2013
}

\begin{abstract}
Pineapple is a delicious tropical fruit with a fine flavour and high nutritive value. It is one of the most important commercial fruit crops in the world. Despite its popularity, no proper data on the costs of its production in Nigeria are available. The study determines profitability and constraints of pineapple production in Osun State, Nigeria. Multistage sampling technique was used to obtain information from 50 respondents using purposive and random selection. Data collected were analysed using descriptive statistics and budgetary technique. Results indicated that majority of the farmers were males, aged 53.7 years on average and engaged full time in pineapple production. The modal level of farmer's education was primary. The average period of experience in pineapple farming was 13.5 years. The gross margin and net profits in Naira (Nigerian currency) were $\$ 182725$ and $\$ 162$ 045, respectively. The questionnaire in the study contained the most serious problems confronting pineapple farmers: limited availability of high quality planting materials, high fruit perishability, low fruit prices, low access to credits and plant diseases. Availability of high yielding pineapple varieties, establishment of cold storages to reduce fruit perishability, agricultural price support programmes, easier access to credit from formal sources and farmers' education were considered essential to improve productivity and profitability of pineapple production in Nigeria.
\end{abstract}

Key words: Ananas comosus, costs and profitability of production, constraints of production, Nigeria

\section{INTRODUCTION}

Pineapple (Ananas comosus L.) Merr.) belongs to the family Bromeliaceae. It is known as the queen of fruits because of its excellent flavour and taste. According to Ubi et al. (2005), the pineapple plants are drought tolerant and well adapted to the tropical sandy soils with $\mathrm{pH}$ ranging from 4.5 to 6.5 . The plants are propagated from suckers or from the crowns, which grow on top of the fruit. It is one of the most important commercial fruit crops in the world available throughout the year. Pineapple production in 2011 constituted more than 19 million MT (metric tons) (FAOSTAT 2013). Thailand is the largest producer of pineapple, accounting for $13 \%$ of global output, followed by Brazil and Costa Rica. Production of pineapple in Nigeria accounted 1.4 million MT in 2011 (about 7\% of the world production), which placed it in the seventh position (FAOSTAT 2013). The fruits are used mainly for fresh consumption and fruit juice, while in some parts of the world the fermented juice is used to make vinegar and alcoholic spirit. Leaves can be used in three forms: fresh, dried and in silage (Geocoppens 2001). Centrifuge sludge left over from juice production may be used as pork feed (FAO 2004), while fruit core is used for preparing candy. The leaves yield a silky fibre, which is used for making a fine fabric popularly known as piña cloth in the Philippines and Taiwan. Pineapple fibres in some countries are exploited for paper production. Pineapple is also used as ornamentals symbolizing welcome, high living and opulence.

Pineapple is a well-positioned fruit since its trade is oriented towards developed countries such 
as Japan, the USA and the European Community (Coveca 2002). The pineapple is the third most important tropical fruit crop after banana and citrus (Hassan et al. 2012), contributing to over 20\% of the world production of tropical fruits (Coveca 2002). In countries producing the pineapple, nearly $70 \%$ is consumed as fresh fruit.

In Nigeria, pineapple production is the main source of income for many farmers. Until recently, about $80 \%$ of the fruits came from small farms managed under mixed cropping systems (Kochhar 2006). However, there are no proper data on economics of its production. The accurate figures on establishment cost, operating cost and labour input requirement in pineapple orchard would be of a great importance for pineapple producers as well as for financing institutions. The general objective of the study therefore is to determine profitability and constraints of pineapple production in Osun State, Nigeria. Specifically, the study objectives are to determine (i) the socio-economic characteristics of pineapple producers and pineapple farms enterprises, (ii) associated costs and returns and (iii) constraints to pineapple production. This study will assist the present or potential pineapple farmers in identifying problems associated with pineapple farming and agricultural policy makers in taking decisions and making recommendations that will improve production and profitability of pineapple enterprises.

\section{MATERIALS AND METHODS}

The study was conducted in the most popular pineapple growing area of Osun State in south-western Nigeria. The study area occupies 2 local government areas (LGAs) out of the 30 LGAs in the State. It is located on the forest savannah mosaic with an annual rainfall of $1570 \mathrm{~mm}$ and temperature between 25 and $27.5{ }^{\circ} \mathrm{C}$. It lies between 6.83 and $6.88^{\circ} \mathrm{N}$ latitude and 4.21 and $4.26^{\circ} \mathrm{E}$ longitude. The two LGAs are semi-rural communities, occupying an area of $588 \mathrm{~km}^{2}$ with a population density of 326 person $\cdot \mathrm{km}^{-2}$. A three-stage sampling technique was used for selecting pineapple farmers. The first stage involved purposive selection of two LGAs (most popular pineapple growing areas). The second stage was the selection of five villages from each of the two LGAs. The final and third stage involved the selection of 6 farmers from each of the villages earlier selected using simple random selection method at each sampling stage to make 60 respondents. Pretested structured questionnaire was used to collect information from the pineapple farmers. The data collected included socio-economic characteristics of the farmers and the farms, price and quantity of inputs used and output produced and problems associated with pineapple farming. Data were collected from May to October 2011. Descriptive statistics was used to describe the socio-economic characteristics and identify production constraints. A budgetary analysis was used to determine the profitability of production. A farm budget is divided essentially into the sections of revenue, variable cost, fixed cost, and return to management. The total fixed cost was calculated using straight-line method with the value of the used-up material assumed to be zero.

\section{RESULTS AND DISCUSSION}

\section{Socio-economic characteristics of the pineapple farmers}

Out of the 60 copies of the questionnaire returned only 50 were found analysable. The 50 respondents consisted of $86 \%$ males and $14 \%$ females, which indicate that the enterprise ownership is male-dominated (Table 1). This may be a result of the labour-intensive nature of the enterprise, which could be very hectic and time consuming, especially for females, who would have to combine this activity with their domestic work. The farmers were between 30 and 70 years of age. The mean age of respondents was 53.7, which shows that the farmers are relatively old considering that the average life expectancy in Nigeria is 42 years. This contradicts the findings of Fakayode et al. (2012) who reported that $61.3 \%$ of the vegetable growers fall within the age bracket $21-40$ years. This generally high age of pineapple farmers could have negative implications on the future pineapple cultivation in the study area (FAOSTAT 2009). About $21 \%$ of the respondents had no formal education while $50 \%$ completed primary school. 
Table 1. Characteristics of pineapple farmers and farms in Osun State, Nigeria, based on 50 questionnaires

\begin{tabular}{|c|c|c|}
\hline Characteristics & $\begin{array}{c}\text { Distribution } \\
(\%)\end{array}$ & Average \\
\hline \multicolumn{3}{|c|}{ Age (years) } \\
\hline $30-39$ & 10.0 & \multirow{4}{*}{53.7} \\
\hline $40-49$ & 18.0 & \\
\hline $50-59$ & 42.0 & \\
\hline $60-69$ & 30.0 & \\
\hline \multicolumn{3}{|c|}{ Sex } \\
\hline Male & 86.0 & \\
\hline Female & 14.0 & \\
\hline
\end{tabular}

\begin{tabular}{|c|c|c|}
\hline \multicolumn{3}{|c|}{ Literacy level (years of education) } \\
\hline No formal education & 21.0 & \multirow{4}{*}{6.1} \\
\hline Primary education (6) & 50.0 & \\
\hline Secondary education (10) & 25.0 & \\
\hline Tertiary education (15) & 4.0 & \\
\hline \multicolumn{3}{|c|}{ Farming experience (years) } \\
\hline $5-9$ & 10.0 & \\
\hline $10-14$ & 28.0 & \\
\hline $15-19$ & 40.0 & 13.5 \\
\hline $20-24$ & 12.0 & \\
\hline Above 24 & 10.0 & \\
\hline \multicolumn{3}{|c|}{ Mode of farming } \\
\hline Full time & 82.0 & \\
\hline Part time & 18.0 & \\
\hline \multicolumn{3}{|c|}{ Sources of financing } \\
\hline Personal savings & 60.0 & \\
\hline Loan & 10.0 & \\
\hline Inheritance & 30.0 & \\
\hline
\end{tabular}

Less than $25 \%$ of the pineapple farmers had secondary education, and $4 \%$ possessed post-secondary school certificate. On average, the respondents have had six years of formal education, which is the primary school duration period in Nigeria. The poor literacy level of the respondents could affect their choice of inputs and the utilization of existing inputs and their willingness to adopt improved technologies. Most (82.5\%) of the pineapple farmers were smallholders cultivating on average 1.3 ha and might require financial support to produce on a larger scale. This observation confirms the report of Onaiwu (2011) that small-scale producers dominate pineapple production in Edo State. Of these respondents, $82 \%$ were full-time farmers while $18 \%$ were farming part time with off-farm employment to augment income. About $10 \%$ of the pineapple farmers in the study area had between 5 and 9 years of experience and $62 \%$ had more than 15 years of experience. The average farming experience for the pineapple farmers is 13.5 years, which indicates that farmers were not new to pineapple cultivation and knowledgeable on the operations and constraints of pineapple production (Table 1). High proportion $(60 \%)$ of the respondents used personal savings to finance the farming enterprise, $10 \%$ had access to loans, and the remaining 30\% inherited the farm land.

\section{Budgetary analysis}

The estimated costs and revenue of pineapple enterprise were $\$ 197955$ and $\$ 360$ 000, respectively (Table 2). The gross margin and return to management were $\$ 182725$ and $\$ 162$ 045, respectively. The profit margin was $45 \%$ while rate of return on investment was $81.9 \%$. In general, narrow profit margins indicate increased volatile earnings. For enterprise with significant fixed costs, wide profit margins could reduce the risk that a decline in sales will cause a net profit loss.

A value of 0.492 (49.2\%), estimated as operating expense ratio of pineapple enterprise, indicates that $49.2 \%$ of total revenue was used to cover operating expenses. The benefit to cost ratio of pineapple enterprise implied that for every 1 spent on the enterprise, 0.8 was returned as profits. These ratios are indicative of the profitability of pineapple enterprise in the study area. Profitability of pineapple production appears to be low but is not in comparison with other fruit crops (Afolami \& Ayinde 2001; Tijani et al. 2010). The reasons for the low profit were shortage of improved planting materials, low level of production technology and high perishability of the crop, which led to low output price.

\section{Constraints to pineapple production}

The constraints that affect production and profit of pineapple production are presented in Table 3 . The most prevalent constraints to pineapple production in the study area in descending order of importance are shortage of high quality planting materials (valuable genotypes and free of pathogens), high fruit perishability, low sale price, lack of access to credit and plant diseases. 
Table 2. Average enterprise budget output for pineapple production on 1 ha in Osun State, Nigeria, based on 50 questionnaires

\begin{tabular}{lr}
\hline \multicolumn{1}{c}{ Item } & Mean amount \\
\hline \multicolumn{2}{c}{ Revenue } \\
\hline Income from fruits $(10200 \mathrm{~kg}$ & 306000 \\
output at $* 30 / \mathrm{kg})$ & 54000 \\
Income from suckers & 360000 \\
Total revenue (TR) & \multicolumn{2}{c}{ Variable costs (VC) }
\end{tabular}

\section{Labour cost:}

Land preparation and planting

28000

Weeding

9340

Fertilizer application

11120

Pesticide application

9000

Harvesting and marketing

31340

Total labour cost

88800

Inputs cost:

Pineapple suckers $\quad 54000$

Fertilizers $(312.5 \mathrm{~kg}$ at $100 / \mathrm{kg}) \quad 31250$

Herbicides ( $3 \mathrm{~L}$ at $\$ 850 / \mathrm{L}$ ) 2550

Pesticides (0.9 L at 750/L) 675

Total cost of inputs $\quad 88475$

Total variable cost (TVC) 177275

Gross margin (TR - TVC) 182725

\begin{tabular}{lr}
\hline \multicolumn{2}{c}{ Fixed costs (FC) } \\
\hline Land rent & 6000 \\
Machetes & 1100 \\
Hoes & 430 \\
Wheelbarrows & 10500 \\
Baskets & 2328 \\
Knifes & 322 \\
Total fixed costs $(\mathrm{TFC})$ & 20680 \\
\hline \multicolumn{1}{c}{ Others } \\
\hline Total cost $(\mathrm{TC})=\mathrm{TVC}+\mathrm{TFC}$ & 197955 \\
Net profit $(\mathrm{NP})=\mathrm{TR}-\mathrm{TC}$ & 162045 \\
Profit margin $(\%)=\mathrm{TR} / \mathrm{TC} \times 100 \%$ & $45 \%$ \\
Rate of return on investment & \\
(RORI) $=\mathrm{NP} / \mathrm{TC}$ & \\
Operating expense ratio $(\%)=$ & \\
TVC/TR $\times 100$ & \\
Benefit to cost ratio $(\mathrm{BCR})=$ & \\
TR/TC & \\
\hline
\end{tabular}

${ }^{*} \mathbb{N}($ Nigerian currency) $=1 \$=163$
Table 3. Constraints to pineapple production in Osun State, Nigeria, based on 50 questionnaires

\begin{tabular}{lcc}
\hline \multicolumn{1}{c}{ Production constraint } & $\begin{array}{c}\text { Number of } \\
\text { farmers }\end{array}$ & $\begin{array}{c}\text { Percentage } \\
(\%)\end{array}$ \\
\hline Lack of improved plant- & 25 & 50 \\
ing materials & 15 & 30 \\
High fruit perishability & 5 & 10 \\
Low fruit price & 3 & \\
Lack of access to formal & 2 & 6 \\
credits & & 4 \\
Plant disease & & \\
\hline
\end{tabular}

This conform with Kayitesi (2011) who observed that inadequate planting materials, unhealthy (diseased) planting materials and poor farming practices, little access to credits, high transport costs and poor routes from the farms to the main highways and lack of adequate market information are constraints to small-scale pineapple growing in Ngoma District of Rwanda.

Shortage of high quality planting materials was ranked as the first constrain by $50 \%$ of the farmers. This resulted in low production and productivity because the local variety used in cultivation by majority of the farmers does not give a high yield. A high quality planting material enables dense planting. Hence, this calls for technological development to increase planting density in order to increase the productivity of the crop. Almost $30 \%$ of the respondents complained on perishability of the product. This agrees with the findings of Amao et al. (2011) who reported that perishable nature of pineapple is the major constraint to pineapple trade in selected markets of Osun State, Nigeria. Storage of the agricultural commodities has a very important role to play to enhance the shelf life of the products and thus offer the commodity for sale in a phased manner to avoid unnecessary glut on the market and therefore the slump in the prices. The problem is more acute in the case of perishable commodities like pineapple.

Mature pineapple fruits cannot be stored for more than 4-5 days after harvesting. Therefore, fruits should be placed on leaves or a sawdust bed alternated with crowns, to avoid any injury to fruits while transporting to major consumption centres. It is not advised to pile up too many layers of fruit. 
The establishment of cold storages would improve the marketability of the fruit. Nearly $10 \%$ of farmers faced the problem of low fruit price. The highly perishable nature of pineapple coupled with lack of effective storage and preservation technology results in dumping of all harvests on the market thereby creating gluts and slump in the prices. The study revealed that the producers' share in consumer price is very low contrary to market intermediaries that shares are higher than producers are. In order to reduce unnecessary intermediaries, the producers themselves can market the produce at a distant market by collective marketing process. Six percent of the respondents mentioned unavailability of formal credit. They could not get credit from institutional agencies; the source of their credit was moneylenders. This resulted in high cost of borrowing. Provision should be made by the governments and other stakeholders in the agricultural sector to provide pineapple farmers with access to credit through micro financing institutions and informal sources. Furthermore, extension agencies should monitor the beneficiaries of such loans to ensure that farmers do not divert these funds for other purposes and repay the loans regularly.

Heart rot of pineapple caused by Dickeya $d a$ dantii (Erwinia chrysanthemi) was another major problem, which needs to be addressed effectively, that was indicated by $4 \%$ of respondents. Research and extension machinery has to be geared up in the study area to educate farmers on the needs for good drainage and dipping the suckers in Bordeaux mixture before planting.

The poor literacy level of the respondents could affect the effectiveness of pineapple farmers' training, which in turn can affect the yield and production efficiency and the income. This confirms the earlier conclusions of Adinya (2001) and Idiong et al. (2006) that technical and commercial education broaden the knowledge of farmers and enable them to farm intelligently, accurately and efficiently, leading to increased yield, productivity and farm income.

\section{CONCLUSIONS}

The survey of pineapple production in Osun State of Nigeria based on 50 questionnaires enables to the following conclusion:

1. Pineapple production is male-dominated, the mean age of farmers is 53.7 years, $50 \%$ have primary school education, they are smallholders (1.3 ha) and their farming experience is 13.5 years.

2. The mean net profit is 162045 per ha.

3. The main constraints are: lack of high quality planting materials, high fruit perishability, low fruit price, lack of access to formal credits and plant diseases.

4. High proportion $(60 \%)$ used personal savings to finance the farming enterprise, $10 \%$ had access to loans, and the remaining $30 \%$ inherited the farmland.

\section{REFERENCES}

Adinya I.B. 2001. Factors influencing labour utilization in small-scale cassava production: A case study of Uyo agricultural zone of Akwa Ibom state. Unpublished M.Sc. dissertation, University of Uyo, Akwa Ibom state, 69 pp.

Afolami C.A., Ayinde I.A. 2001. Economics of tomato production in Yewa North area of Ogun state, Nigeria. Agro-Science 2(1): 17-23. DOI: 10.4314/as.v2i1.1475.

Amao I.O., Adebisi-Adelani O., Olajide-Taiwo F.B., Adeoye I.B., Bamimore K.M., Olabode I. 2011. Economic analysis of pineapple marketing in Edo and Delta states, Nigeria. Libyan Agric. Res. Cen. J. Int. 2(5): 205-208. http://www.idosi.org/larcji/2(5)11/1.pdf.

Coveca C.A. 2002. Comision veracruzana de comercializacion agropecuaria. Gobierno del Estado de Veracruz, México [in Spanish].

Fakayode S.B., Rahji M.A.Y., Adeniyi S.T. 2012. Economic analysis of risks in fruit and vegetable farming in Osun state, Nigeria. Bangladesh J. Agril. Res. 37(3): 473-491. DOI: 10.3329/bjar.v37i3.12125.

FAO 2002. www.fao.org/inpho/content/compend/text/ ch33/AE614e01.htm.

FAO 2004. www.fao.org/livestock/agap/frg/afris/espanol.

FAOSTAT 2009. Top 5 facts sources: Food and Agriculture Organization of the United Nations. www.top5ofanything.com/index. 
Geocoppens 2001. www.ciat.cgiar.org/ipgri/ fruits_from_americas/d'Eeckenbrugge [in French].

Idiong I.C., Agom D.I., Ohen. S.B. 2006. Comparative analysis of technical efficiency in swamp and upland rice production systems in Cross Rivers State, Nigeria. 20 ${ }^{\text {th }}$ Annual National Conference of Farm Management Association of Nigeria Federal College of Forestry, Jos Plateau State, Nigeria. $18^{\text {th }}$ $21^{\text {st }}$ September, pp. 425-432.

Kayitesi R. 2011. Factors affecting small scale farmers' pineapple production: the study of Ngoma District, Rwanda. Unpublished Professional Master Degree in Management of Development Van Hall Larenstein University of Applied Sciences, Rwanda. 51 pp.

Kochhar S.L. 2006. Economic botany in the tropics. Macmillan India. 203 pp.
Onaiwu S.A. 2011. Economic analysis of pineapple production: A case study of Esan west and Uhunmwode Local Government Areas of Edo State, Nigeria. Unpublished M.Sc. Dissertation, Ahmadu Bello University, Zaria, 69 pp.

Tijani A.A., Ayanwale A.O.S., Baruwa O.I. 2010. Profitability and constraints of tomato production under tropical conditions. International Journal of Vegetable Science 16(2): 128-133. DOI: 10.1080/19315260903309763.

Ubi W., Iqwe H., Ekpe S., Ibor O. 2005. Preliminary trial of fertilizer types on pineapple (Ananas comosus) grown on coastal and sands of Cross River State, Nigeria. Global J. Pure and applied sci. 11(4):457-460. DOI: $10.4314 /$ gjpas.v11i4.16534. 